\title{
Short Communication: Genetic resources of fast-growing tree for rehabilitating upland area of deteriorated Saguling catchment, West Java, Indonesia
}

\author{
HENTI HENDALASTUTI RACHMAT ${ }^{1, \boldsymbol{v}}$, ATOK SUBIAKTO ${ }^{1}$, ARIDA SUSILOWATI ${ }^{2, v \vee}$ \\ ${ }^{1}$ Forest Research and Development Center. Jl. Raya Gunung Batu No. 5, Bogor 16118, West Java, Indonesia. Tel.: +62-251-8633234; 7520067. \\ Fax. +62-251-8638111, `email: hendalastuti@yahoo.co.uk \\ ${ }^{2}$ Faculty of Forestry, Universitas Sumatera Utara. J1. Tri Dharma Ujung No 1, Kampus USU, Medan, North Sumatra, Indonesia. \\ Tel./fax.: +62-61-8220605. "vemail: arida_iswanto@yahoo.co.id
}

Manuscript received: 26 October 2018. Revision accepted: 24 January 2019.

\begin{abstract}
Rachmat HH, Subiakto A, Susilowati A. 2019. Title. Short Communication: Genetic resources of fast-growing tree for rehabilitating upland area of deteriorated Saguling catchment, West Java, Indonesia Biodiversitas 20: 442-447. Representing the upper landscapes area in West Bandung District, West Java Province, Indonesia with the highest point of $\pm 650 \mathrm{~m}$, Saguling reservoir covers catchment area of about \pm 2300 ha. Many huge reservoirs in Indonesia experienced faster-observed sedimentation than those of its expected time. The main cause for this situation is that the sedimentation rate has been doubled or even more than that of calculated or expected. The phenomenon of excessive and accelerated sedimentation condition in a water reservoir indicated that the development of both areas and its community have neglected the conservation aspect of the catchment areas. Those, rehabilitation of catchment area become an urgent need. Related to rehabilitation purposes, we planted six fast-growing tree species (Ochroma pyramidale/balsa, Nauclea orientalis/gempol, Ficus variegate/nyawai, Antocephalus cadamba/jabon putih, Anthocephalus macrophyllus/jabon merah, and Octomeles sumatrana/binuang bini) to determine which ones were the most suitable for scale-up plantation in rehabilitation activities. Planting was designed by total planting in uniform planting distance of $3 \times 3 \mathrm{~m}$, each species planted in line planting technique consisted of 3 block replications. Measurement on seedling height was conducted over all species at 6 and 12 months after planting. The best height increment showing the fastest growing species at 6 months after planting then scaled up to bigger experimental plot covering 3 ha area. Of the sixth month after planting measurement, result showed balsa gained the highest average height $(136.19 \mathrm{~cm})$ followed by nyawai, binuang bini, jabon merah, jabon putih and gempol $(133.53 \mathrm{~cm}, 99.60 \mathrm{~cm}, 78.27 \mathrm{~cm}, 70.60 \mathrm{~cm}$, and $53 . .30 \mathrm{~cm})$. Scaled up experimental plot for balsa showed the average height at 1.5, 2.5 and 3.5 year after planting (yap) was $4.16 \mathrm{~m}, 12.13 \mathrm{~m}$, and $23.08 \mathrm{~m}$ while the average diameter breast height (DBH) was $7.0 \mathrm{~cm}, 20.14 \mathrm{~cm}$ and $28.21 \mathrm{~cm}$. From study result, we suggested balsa as potential fast growing tree species planted for rehabilitation activities in Saguling catchment area.
\end{abstract}

Keywords: Genetic resources, landscape change, rehabilitation, Saguling reservoir

\section{INTRODUCTION}

Saguling dam and reservoir that has a catchment area of $2.283 \mathrm{~km}^{2}$ is located as Citarum River in West Bandung District, West Java Province, Indonesia (Lianos et al. 2003). It is surrounded by hilly landscapes of catchment area that contributed to water supply of the reservoir. The increasing population growth has a significant pressure on land use of the Saguling catchment area. This condition is worsening with $50 \%$ of local community residing along the Saguling reservoir, are farmers with high population growth and high dependency on. Rapid increment on population size has forced people to use land intensively, and at some points, land encroachment happened to those allocated for water catchments land (jabarprov.go.id). Far for its function as the water catchment, the surrounding area of Saguling reservoir has shifted to many forms such as agricultural lands, shrubs and abandoned area, alangalang grassland, and even sporadic temporal settlements.

Forested lands of catchment areas, which would have provided natural vegetation cover has been removed and replaced with crops and also changed into grassland. These two kinds of land use yielded much more run-off than that of forested land itself. Intensive land use, such as farmland, would trigger soils to be more compact and thus reduces their permeability, making it more difficult for rain to penetrate the soil. In other hands, the condition was worsened by the fact that short cropped species and grasses and also flat fields will offer little resistance to run-off and overland flow. Those, land use change to several scenarios (Li et al. 2007; Khadka 2014) has a different level of hydros those of complicated problems rising on the change of land use and function, it generates new disaster when flooding and landslide have been recorded more frequent lately.

Reforesting Saguling water catchment area will have several benefits for its ecosystem (Nowak 2017). The simplest benefit is that tree canopy can intercept some rain and reduces the risk of extreme run-off and cover flow. The effects of trees on the soil are more apparent to observe. Fallen tree leaves will create favorable microclimate thus support microbes to work and hence support the formation of deeper, humus-rich soil. The thick surface roots that are formed when vegetation grow densely covers the land 
surface will intercept the overland flow of rainwater. Deep penetrating sub-surface root into the soils would also make soil more permeable to be passed. All those benefits have set trees as a possible solution to both flooding and also landslides while increasing land productivity itself.

Rehabilitation on upper stream Saguling reservoir needs a complex consideration when ecological function should meet social and economic benefit. It is a fact that land in upper stream Saguling reservoir legally is state-owned land; however, it was delivered to local community for its land-use management. Thus, the landscape has been cultivated for crops and other agricultural uses. Improper management of agricultural use of the land has led to the existence of abandoned and unproductive farmlands. In this situation, rehabilitation of degraded landscape should always consider the socio-economic aspect.

The objective of the study was to determine which species was the most suitable one for scale-up plantation in rehabilitation activities of deteriorated upper stream Saguling reservoir. This will be a good input for the scheme of urban watershed forestry in choosing appropriate species that could give multi-benefit at once.

\section{MATERIALS AND METHODS}

\section{Study area}

Saguling, Cirata, and Jatiluhur dam reservoirs are arranged in a series along the Citarum River which flows northwestward to the Java Sea through West Java, Indonesia (Figure 1). These reservoirs provide hydropower, irrigation water, domestic water to Jakarta (Jatiluhur) and aquaculture opportunities (Saguling and Cirata). Saguling reservoir is the upper of the three reservoirs. It is located about $30 \mathrm{~km}$ west of Bandung and about $100 \mathrm{~km}$ south-east of Jakarta. The water contribution for these dams is Citarum River which is $350 \mathrm{~km}$ long from its source in the area surrounding Wayang Mountain. Planting site was located for about $1 \mathrm{~km}$ away from the Saguling water dam reservoir.

According to Köppen and Geiger grouping, Saguling classified as Af climate. The average annual temperature is $26.0^{\circ} \mathrm{C}$ with average precipitation was $3793 \mathrm{~mm}$. In January, the precipitation reaches its peak, with an average of $461 \mathrm{~mm}$. The least amount of rainfall occurs in August. The temperatures are highest on average in April, at around $26.6^{\circ} \mathrm{C}$. At $25.0^{\circ} \mathrm{C}$ on average, July is the coldest month of the year (https: //en.climate-data.org).

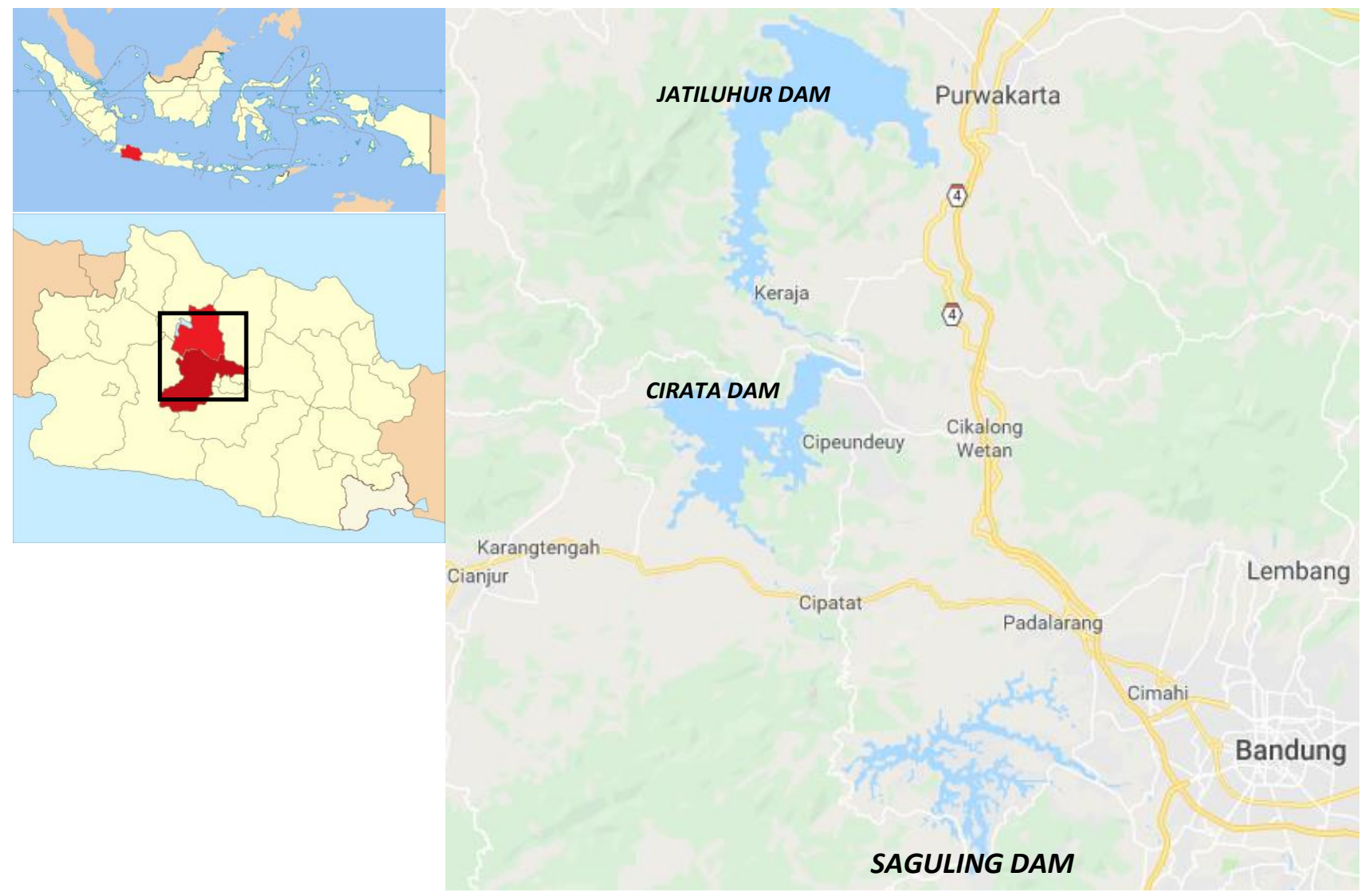

Figure 1. Location of Saguling water reservoir, West Java, Indonesia (Abery et al. 2005) 


\section{Planting scheme}

We planted six fast-growing tree species, i.e. Ochroma pyramidale (balsa), Nauclea orientalis (gempol), Ficus variegate (nyawai), Antocephalus cadamba (jabon putih), Anthocephalus macrophyllus (jabon merah), and Octomeles sumatrana (binuang bini) to determine which one was the most suitable for scale-up plantation in rehabilitation/ reforestation/plantation forestry activities. Planting was designed by in uniform planting distance of $3 \times 3 \mathrm{~m}^{2}$, each species planted in line planting technique consisted of 3 block replications. Since almost all area in Saguling reservoir has been managed by a local community for agricultural production, planting system adapted the agroforestry technique where trees were intercropping with cash crops (corn, edible nuts, etc). Measurement on seedling height was conducted over all species at 6 and 12 months after planting (map). The fastest growing species at 6 months after planting (map) then scaled up to bigger experimental plot covering 3 ha area adjacent to species trial plot location. It means that at month 7 th; we established 3 ha experimental plot planted with the fastest growing tree based on previous experiment.

\section{Data analysis}

Parameter assessed in this study was carried out at 6 and 12 maps for all six planted fast-growing species, including total height (6 and 12 maps) and diameter at breast height/DBH (at 12 maps). Measurements were continued to that of the fastest growing species (balsa) at the age of 3 years after planting (yap). Considering the homogeneity of seedlings size, we measured total height by using trigonometry principles from ground level to the point where the top part of the tree. At 12 map, we also measured DBH as well as their total height because in general, the trees height had reached over $1.3 \mathrm{~m}$. For the survival rate of the planted tree within the study plot, the calculation was made using the following formula:

$$
\begin{aligned}
& \text { Survival rate, } \mathrm{X}=(\mathrm{Z} / \mathrm{Y}) \times 100 \% \\
& \text { Where, } \\
& \mathrm{X}=\text { Survival rate of planted trees } \\
& \mathrm{Y}=\text { Total planted trees } \\
& \mathrm{Z}=\text { Total number of standing trees }
\end{aligned}
$$

Mean value was calculated both for total height and DBH. Further analysis was carried out using analysis of variance to determine whether species significantly showed different performance at planting site, followed by Duncan multiple range tests to identify their performance ranks. Calculation was executed by using SPSS 11 .

\section{RESULTS AND DISCUSSION}

\section{Growth performance of six fast-growing species planted at Saguling reservoir}

Plantation forestry is increasingly important land use in Indonesia, especially in Java as the need between establishing the forested landscape and community demands on land resources is high. One term related to establishing forested landscape has been carried out by means of artificial methods, such as planting or direct seeding, on land where a forest would not have grown naturally or to forest vegetation that has previously been removed. Another way of establishing forest is carried out by the term of a plantation which is defined as artificially forested area, usually consisting of a single species (Zhang et al. 2007).

Saguling reservoir landscapes characterized by its land use as agricultural land and also fishery cultivation. Thus, land dependency from surrounding community is high. Population growth has also caused increasing demand for land use change from forested land into more intensively managed land such as agriculture. In this manner, selecting appropriate and preferable tree species is important so that land conversion can be managed at the slowest rate. Appropriate tree species were the important key for the successfulness of afforestation program. Selected trees must be beneficial trees species, economical and ecological benefit, preferred by local people and fast-growing timber trees (Xu et al. 2012). For the successful strategy, tree species must be chosen carefully to address local people's perceived needs. The selection involves identifying and prioritizing the farmer's needs and preferences in forest tree management and utilization. Furthermore, by considering local environmental knowledge, a participatory approach helps to identify tree species for selection that can meet both social and environmental needs (German et al. 2006). Our study focused on selecting the best species that has highest performance on its growth at relatively short time in upper area of Saguling reservoir. When best tree has been found, planting scheme that meets all the aspect can be easily designed. Prior to planting activities, we did agreement with the farmers'/landholders that their agricultural activity should not make any disturbance to planted trees.

Our study determined that balsa species significantly showed different performance when planted at Saguling reservoir. Table 1 showed the result for analysis of variance from the six fast-growing species that indicated the total tree height at 6 maps significantly different among 6 species planted, however, at 12 maps the differences seemed not significant. Table 2 showed the result of Duncan multiple range tests to determine species rank where balsa and nyawai provided the highest and significant tree height among others and at 12 map balsa still gave the highest performance for its total height. Figure 2 showed the field performance of balsa and gempol tree that differs markedly. Even though we planned to calculate survival rate of planted seedlings, it seemed no more needed in later discussion because the mortality was low (3-5\%, data not shown) and landholders had a very good response related to this planting experiment by replanting the dead seedlings with similar species allocated for such cases. Numbers of extra seedlings that were not used for replanting were given freely to farmers/ landholders to be planted at their lands in different locations. 


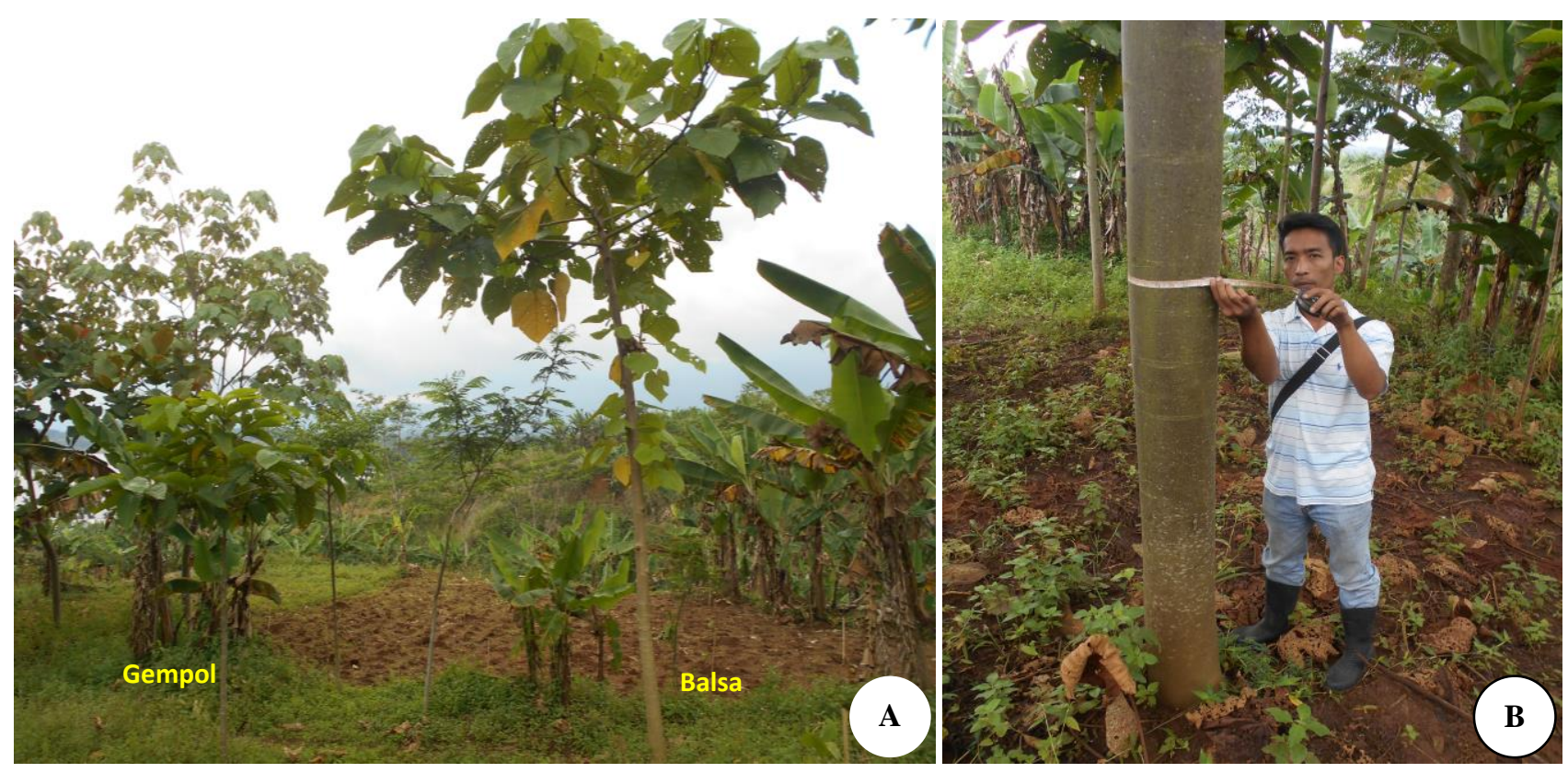

Figure 2. A. One-year-old balsa and gempol performance in the field. B. Balsa tree diameter at 3 years after planting

Table 1. Recapitulation of analysis of variance for the parameter of total height and DBH of six fast-growing species at 6 and 12 map

\begin{tabular}{lccccc}
\hline \multicolumn{1}{c}{ Source } & DF & Type I SS & Mean square & F-value & Pr $>$ F \\
\hline $\begin{array}{l}\text { Tree species } \\
\begin{array}{l}\text { Measurement on DBH at 12 map } \\
\text { Tree species }\end{array}\end{array}$ & 5 & 97.217 & 19.443 & 39.18 & $<0.0001 * *$ \\
$\begin{array}{l}\text { Measurement on total tree height at 12 map } \\
\text { Tree species }\end{array}$ & 5 & $65,355.117$ & $13,071.023$ & 1.25 & 0.3551 \\
Measurement on total tree height at 6 map & 5 & $17,449.434$ & $3,489.886$ & 15.53 & $0.0002 * *$ \\
\hline
\end{tabular}

Table 2. Recapitulation of Duncan post-hoc test of six fastgrowing species at Saguling reservoir area

\begin{tabular}{lccc}
\hline \multirow{2}{*}{ Tree species } & \multicolumn{3}{c}{ Mean value of measured parameter } \\
\cline { 2 - 4 } & $\begin{array}{c}\text { Total height } \\
(\mathbf{c m}), \mathbf{6} \text { map }\end{array}$ & $\begin{array}{c}\text { Total height } \\
(\mathbf{c m}), \mathbf{1 2} \text { map }\end{array}$ & $\begin{array}{c}\text { DBH }(\mathbf{c m}), \\
\mathbf{1 2} \text { map }\end{array}$ \\
\hline Balsa & $136.19^{\mathrm{a}}$ & $295.62^{\mathrm{a}}$ & $8.973^{\mathrm{a}}$ \\
Binuang bini & $99.60^{\mathrm{b}}$ & $208.37^{\mathrm{ab}}$ & $4.263^{\mathrm{b}}$ \\
Jabon merah & $78.27^{\mathrm{bc}}$ & $211.08^{\mathrm{ab}}$ & $3.626^{\mathrm{b}}$ \\
Nyawai & $133.53^{\mathrm{a}}$ & $192.51^{\mathrm{ab}}$ & $3.256^{\mathrm{b}}$ \\
Jabon putih & $70.60^{\mathrm{c}}$ & $210.92^{\mathrm{ab}}$ & $3.023^{\mathrm{b}}$ \\
Gempol & $53.30^{\mathrm{c}}$ & $89.17^{\mathrm{b}}$ & $1.543^{\mathrm{c}}$ \\
\hline
\end{tabular}

Note: numbers with one or more same letters in one column was not significantly different

Table 3. Average total height of balsa at 3 ha scale up plantation

\begin{tabular}{ccc}
\hline $\begin{array}{c}\text { Time of } \\
\text { measurement }\end{array}$ & $\begin{array}{c}\text { Average total height } \\
(\mathbf{m})\end{array}$ & $\begin{array}{c}\text { Average DBH } \\
(\mathbf{c m})\end{array}$ \\
\hline 1.5 yap & 4.16 & 7.0 \\
2.5 yap & 12.13 & 20.14 \\
3.5 yap & 23.08 & 28.21 \\
\hline
\end{tabular}

Note: yap= years after planting time
Tree diameter is among the important parameter in assessing the tree growth. Bigger diameter would yield higher volume of timber. Bigger diameter is also preferable since the timber utilization even could be wider than those of smaller diameter tree. Table 1 showed that DBH among 6 different species at 12 map significantly differed. When it was further analyzed by Duncan test, it was determined that balsa has biggest DBH (8.973) among all the species planted and the value was significantly different. At both parameters measured, balsa provided the best performance among others.

\section{Growth performance of 3 years old planted balsa tree and its role for the reservoir area}

Scale up plantation plot for reforestation of the reservoir using the fastest growing species at the site (balsa) showed in Table 3. Ochroma pyramidale or locally known as balsa is known as a very fast-growing tree species with the lightest wood density $\left(0.17 \mathrm{~g} \mathrm{~cm}^{-3}\right)$. Balsa is among the species that has large leaves and able to create a thick leaf-litter biomass cover. It has a narrow, thin crown, and a short life cycle of 15-20 y (Coley 1983; Francis 1991; Dalling et al. 1999; Park and Cameron 2008; 
Selaya et al. 2008). Douterlungne et al. 2010) proposed that large leaves might become the caused for its high density, rapid tree growth and closed canopy cover during its initial early stages or growth. Considering that characteristic, the opportunities to compete with other 5 planted species in this plot trial would increase and was proven as an effective mechanism that balsa leads the highest performance both for height and diameter among others. Laurance et al. (2004) determined that the increase of vertical growth of balsa was taken place due to crown competition between balsa individuals, while stem diameter growth is developed after optimal height is reached, and does not necessarily decline with tree density due to accelerated growth of surviving trees.

When balsa grows dominantly in certain secondary forest by reaching advanced basal area and higher height, restoration process will be facilitated. But, due to its fast leaf turnover, it also increases the soil organic matter accumulation (Levy-Tacher and Golicher 2004; Diemont et al. 2006; Douterlungne et al. 2010), and thus causing a structural barrier for seedling establishment. In other hands, if afforestation extends to the edge of the reservoir, forest litter and or organic matter accumulation may have an impact on aquatic ecosystem productivity. Furthermore, forest soils covered by a thick litter of fallen leaves will have a high infiltration and water storage capacity. When it is combined with their ability to slow water flow through the landscape, afforested reservoir catchments would have high potential for groundwater/aquifer recharge. Furthermore, leafy canopy would intercept rainfall, making the water flow slower reaching the ground and forest floor. It also acts similar to a sponge that Kays (1980) determined it typically could absorb up to 18 inches of precipitation (depending on soil composition) before gradually releasing it to natural channels and recharging groundwater. Other studies (Bharati et al. 2002) have also found similar results when comparing hourly infiltration rates and soil bulk density of forested areas with crops and grazed pasture showing how forest would give beneficial use on managing hydrological process especially in reservoir or a water catchment area.

The overall objective for this kind of activities is those both the surrounding afforested catchment and the reservoir can contribute to flooding risk and sediment reduction. Furthermore, forested soils with their greater surface roughness, higher infiltration capacity, and greater water holding capacity have the potential to slow flows through a catchment, moderating peak flows and maintaining base flows. The filtering function of the trees can also contribute to improved water quality in the reservoir when the surrounding watersheds are forested (Scott et al. 2004; Ballinger 2011; Roger et al. 2017).

In conclusion, our research pointed out that, among six fast-growing tree species planted in upper area of Saguling reservoir, balsa showed the best performance both in term of total tree height and also DBH. At around 3.5 years after planting, balsa has reached a remarkable size and can be proposed to be planted in wider scale. Planting scheme (agroforestry, pure plantation, mixed planting) will be depend based on consensus with local landholders.

\section{ACKNOWLEDGEMENTS}

Authors would like to thanks to Project Collaboration between KOMATSU, Japan and Forest Research and Development Agency for funding the research activity.

\section{REFERENCES}

Abery NW, Sukad, F, Budhiman AA, Kartamihardja ES, Koeshendrajana S, Buddhiman, De Silva SS. 2005. Fisheries and cage culture of three reservoirs in West Java, Indonesia; A case study of ambitious development and resulting interactions. Fisher Manag Ecol 12: 315330.

Ballinger J. 2011. Natural buffer placement and downstream flood mitigation in rural Hawkes Bay, New Zealand. [Thesis]. School of Geography, Environment and Earth Sciences Victoria University of Wellington, New Zealand

Bharati L, Lee KH, Isenhart TM, Schultz RC. 2002. Soil-water infiltration under crops, pasture, and established riparian buffer in Midwestern USA. Agrofor Syst 56: 249-257.

Coley PD. 1983. Herbivory and defensive characteristics of tree species in a lowland tropical forest. Ecological Monographs 53: 209- 233.

Dalling J, Lovelock W, Hubbel SP. 1999. Growth responses of seedlings of two neotropical pioneer species to simulated forest gap environments. J Trop Ecol 15: 827-839.

Diemont SA, Martin JF, Levy Thacher SI, Nigh RB, Ramirez Lopez P, Golicher JD. 2006. Lacandon Maya forest management: restoration of soil fertility using native tree species. Ecol Eng 28: 205-212.

Douterlungne D, Levy-Tacher SI, Golicher JD, Roma N, Obeytia F. 2010.Applying indigenous knowledge to the restoration of degraded tropical rain forest dominated by bracken. Restor Ecol 183: 322-329.

Francis JK. 1991. Ochroma pyramidale Cav. Balsa - Bombacaceae. SO. Institute of Tropical Forestry. USDA, SM-41. R'1o Piedras.

German LA, Kidane B, Shemdoe R. 2006. Social and environmental trade-offs in tree species selection: a methodology for identifying niche incompatibilities in agroforestry. Environ Dev Sustain 8 (4): 535-552.

Kays BL. 1980. Relationship of Forest Destruction and Soil Disturbance to Increased Flooding in The Suburban North Carolina Piedmont Proceedings of The Third Conference of The Metropolitan Tree Improvement Alliance. The State University of New Jersey, USA.

Laurance WF, Oliveira AA, Laurance SG, Condit R, Nascimento HEM, Sanchez-Thorin AC, Lovejoy TE, Andrade A, D'angelo S, Ribeiro JE, Dick CW. 2004. Pervasive alteration of tree communities in undisturbed Amazonian forests. Nature 428: 171-175.

Levy-Tacher SI and Golicher JD. 2004. How predictive is traditional ecological knowledge? The case of the Lacandon Maya fallow enrichment system. Interciencia 29: 496-503.

Li KY, Coe MT, Ramankutty N, de Jong R. 2007. Modeling the hydrological impact of land-use change in West Africa. J Hydrol 337 (3): 258-268.

Lianos JA, Yague J, de Ormijana FS, Cabrera M, Perez J. 2003. Dam Maintenance and Rehabilitation. Taylor \& Francis. London.

Nowak DJ. 2017. Assessing the benefits and economic values of trees. In: Ferrini F, van den Bosch CCK, Fini A (eds.). Routledge Handbook of Urban Forestry. Routledge, New York.

Park A, Cameron JL. 2008. The influence of canopy traits on throughfall and stemflow in five tropical trees growing in a Panamanian plantation. For Ecol Manag 255: 1915-1925.

Rogger M, Agnoletti M, Alaoui A, Bathurst JC, Bodner G, Borga M, Chaplot V, Gallart F, Glatzel G, Hall J, Holden J, Holko L, Hom R, Kiss A, Kohnova S, Leitinger G, Lennartz B, Parajka J, Perdigao R, Peth S, Plavcova L, Quinton JN, Robinson M, Salinas JL, Santoro A, Szolgay J, Tron S, van den Akker JJ, Viglione A, Bloschl G. 2017. Land use change impacts on floods at the catchment scale: Challenges and opportunities for future research. Water Resour Res 53 (7): 52095219

Scott DF, Bruijnzeel LA, Vertessy RA, Calder IR. 2004. Impacts of forest plantations on streamflow. Hydrology. DOI: 10.1016/B0-12-1451607/00272-6

Selaya NG, Oomen RJ, Netten JJC, Werger MJA, Anten NPR. 2008. Biomass allocation and leaf life span in relation to light interception 
by tropical forest plants during the first years of secondary succession. J Ecol 96: 1211-1221.

Xu J, van Noordwijk M, He J, Kim K-J, Jo R-S, Pak K-G, Kye U-H, Kim J-S, Kim K-M, Sim Y-N, Pak JU, Song K-U, Jong Y-S, Kim K-C,

Pang C-J, Ho M-H. 2012. Participatory agroforestry development for restoring degraded sloping land in DPR Korea. Agrofor Syst 85 (2): 291-303

Zhang L, Vertessy R, Walker G, Gilfedder M, Hairsine P. 2007. Afforestation in a catchment context. Understanding the impacts on water yield and salinity. Industry Report 01/07. CSIRO Land and Water Science Report 01: 07. 